\title{
Lesions in 224 spleens of splenectomized dogs and evalution of alternative techniques for previous microscopic diagnosis ${ }^{1}$
}

\author{
Rafael S. Figueiredo ${ }^{2}$, Caterina Muramoto ${ }^{3}$, Thanielle N. Fontes ${ }^{2}$, Iris D.S. Meneses ${ }^{4}$, \\ Paula G.S. Cardoso², Carlos H.C. Vieira Filho², Alessandra Estrela-Lima ${ }^{3}$ \\ and Tiago C. Peixoto ${ }^{3 *}$ (D)
}

\begin{abstract}
Figueiredo R.S., Muramoto C., Fontes T.N., Meneses I.D.S., Cardoso P.G.S., Vieira Filho C.H.C., Estrela-Lima A. \& Peixoto T.C. 2019. Lesions in 224 spleens of splenectomized dogs and evalution of alternative techniques for previous microscopic diagnosis. Pesquisa Veterinária Brasileira 39(8):622-629. Departamento de Anatomia, Patologia e Clínicas Veterinárias, Universidade Federal da Bahia, Av. Adhemar de Barros 500, Ondina, Salvador, BA 40170-110, Brazil. E-mail: tcpeixoto@ufba.br

When detecting a proliferative splenic lesion, veterinarians usually choose splenectomy before a conclusive diagnosis, which can provide a deleterious effect to the dog. The most appropriate would be to perform splenectomy as a therapeutic procedure only in cases with real surgical indication, which can be established after defining microscopic diagnosis and prognosis. The objectives of this study were: to determine the frequency of different types of lesions in spleens of splenectomized dogs in the period of 12 years (2006-2017); determine the representativity of neoplastic lesions (benign and malignant) and non-neoplastic lesions; to evaluate and compare the safety and efficiency of fine needle aspiration biopsy (FNA) and ultrasound-guided Tru-cut needle biopsy for cytological and histopathological diagnosis, respectively, of splenic nodular lesions. In the studied period 224 cases of lesions were found in splenectomized spleens. The frequency of non-neoplastic lesions $(50,45 \%, 113 / 224)$ and neoplastic lesions $(49,55 \%, 111 / 224)$ was very similar. Among the neoplastic lesions, the malignant ones were more frequent $(79,27 \%, 88 / 111)$, and the hemangiosarcoma was the most common $(52,25 \%, 58 / 111)$. The possibility of malignant neoplasm was about $74 \%$ greater than a benign one. In summary, it was verified that $60.71 \%(136 / 224)$ of the cases corresponded to benign lesions without indication to splenectomy. FNA techniques and Tru-cut biopsy showed a low risk of complications. Regarding the diagnostic efficacy, the FNA obtained $71.43 \%(15 / 21)$ of conclusive diagnoses, $60 \%(9 / 15)$ of which were compatible with the final result of the histopathological evaluation, after splenectomy (gold standard). The Tru-cut biopsy obtained 71.43\% (5/7) of conclusive diagnoses and $28.57 \%$ (2/7) of inconclusive diagnoses. Among the conclusive one, in $100 \%$ of the cases the diagnosis was compatible with the gold standard. Thus, since the possibility of benign splenic lesions in dogs is 1.52 times greater than malignancies, splenectomy should be recommended as a therapeutic procedure only in cases with proven surgical indication, which can be established after definition of microscopic diagnosis and prognosis. The use of FNA and Tru-cut biopsy should be recommended, especially for small and focal splenic lesions, since such techniques are good alternatives for establishing diagnosis previously to
\end{abstract}

\footnotetext{
${ }^{1}$ Received on April 22, 2019.

Accepted for publication on April 30, 2019.

Part of Master's Thesis of the first author.

${ }^{2}$ Graduate Studies Program in Animal Science in Tropics (PPGCAT), Escola de Medicina Veterinária e Zootecnia (EMEVZ), Universidade Federal da Bahia (UFBA), Av. Adhemar de Barros 500, Ondina, Salvador, BA 40170-110, Brazil.
}

\footnotetext{
${ }^{3}$ Departamento de Anatomia, Patologia e Clínicas Veterinárias, Escola de Medicina Veterinária e Zootecnia (EMEVZ), Universidade Federal da Bahia (UFBA), Av. Adhemar de Barros 500, Ondina, Salvador, BA 40170-110. *Corresponding author: tcpeixoto@ufba.br

${ }^{4}$ Laboratório de Análises Clínicas, Hospital de Medicina Veterinária Prof. Renato Rodenburg de Medeiros Netto, Universidade Federal da Bahia (UFBA), Av. Adhemar de Barros 500, Ondina, Salvador, BA 40170-110.
} 
splenectomy, which may reduce the number of unnecessary splenectomies. The importance of recommending such techniques is emphasized, especially for dogs with focal splenic lesions smaller than three centimeters.

INDEX TERMS: Lesions, dogs, evalution, alternative techniques, diagnosis, splenectomy, splenic biopsy, Tru-cut, neoplasms, cytology. RESUMO.- [Lesões em 224 baços de cães esplenectomizados
e avaliação de técnicas alternativas para diagnóstico
microscópico prévio.] Rotineiramente, frente à detecção de uma lesão proliferativa esplênica, médicos veterinários costumam optar pela esplenectomia antes de se obter o diagnóstico definitivo da lesão esplênica, o que pode trazer consequências deletérias ao cão. 0 mais apropriado seria, contudo, a sua adoção, como medida terapêutica, apenas nos casos com comprovada indicação cirúrgica, o que pode ser estabelecido após o diagnóstico microscópico e prognóstico definidos. Os objetivos desse estudo foram: determinar a frequência dos diferentes tipos de lesão em baços de cães esplenectomizados no período de 12 anos (2006-2017); determinar a representatividade das lesões neoplásicas (benignas e malignas) e não neoplásicas; avaliar e comparar a segurança e a eficiência da punção aspirativa por agulha fina (PAAF) e da biópsia por agulha Tru-cut guiadas por ultrassom para o diagnóstico citológico e histopatológico, respectivamente, de lesões nodulares esplênicas. No período estudado foram encontrados 224 casos de lesões em baços esplenectomizados. A frequência de lesões não neoplásicas $(50,45 \%, 113 / 224)$ e neoplásicas $(49,55 \%, 111 / 224)$ esplênicas foi muito semelhante. Entre as neoplásicas, as de caráter maligno foram mais frequentes $(79,27 \%, 88 / 111)$ e o hemangiossarcoma o mais comum $(52,25 \%, 58 / 111)$. A possibilidade de ocorrência de uma neoplasia maligna foi cerca de $74 \%$ maior do que uma benigna. Em suma, verificou-se que em 60,71\% (136/224) dos casos estudados, tratava-se de lesões benignas que não teriam indicação de esplenectomia. As técnicas de PAAF e a biópsia por agulha Tru-cut demonstraram ter baixo risco de complicações. Quanto à eficácia diagnóstica, pela PAAF obteve-se 71,43\% (15/21) de diagnósticos conclusivos, sendo $60 \%(9 / 15)$ desses compatíveis com o resultado final realizado pela avaliação histopatológica, após a esplenectomia (padrão ouro). Já a biópsia por Tru-cut obteve 71,43\% (5/7) de diagnósticos conclusivos e 28,57\% (2/7) de inconclusivos. Dentre os conclusivos, em $100 \%$ dos casos o diagnóstico foi compatível com o padrão ouro. Desta maneira, visto a possibilidade de ocorrência de lesões esplênicas benignas em cães serem 1,52 vezes maior do que as malignas deve ser recomentado a adoção de esplenectomia, como medida terapêutica, apenas nos casos com comprovada indicação cirúrgica, o que pode ser estabelecido após o diagnóstico microscópico e prognóstico definidos. O uso da PAAF e da biópsia por Tru-cut deve ser recomentado, sobretudo, para lesões esplênicas pequenas e focais, uma vez que tais técnicas representam boas alternativas para o estabelecimento do diagnóstico prévio a esplenectomia, o que pode reduzir o número de esplenectomias desnecessárias. Enfatiza-se a importância da recomendação de tais técnicas, sobretudo para cães com lesões esplênicas focais menores do que três centímetros.

TERMOS DE INDEXAÇÃO: Lesões, caninos, avaliação, diagnóstico, esplenectomia, biópsia esplênica, Tru-cut, neoplasias, citologia.

\section{INTRODUCTION}

The spleen is the largest secondary lymphoid organ in the body and stands out for its role as a defense against microorganisms and antigenic particles, in hematopoietic lymphopoiesis and erythropoiesis, hemocateresis, red blood cell and platelet reserve, in addition to acting on iron metabolism. By virtue of its anatomical and physiological characteristics, the spleen may be involved in many disorders related to inflammatory disease, hyperplasias, as well as benign, malignant and metastatic neoplasms (Tilson 2003).

Routinely, after identifying focal, multifocal or generalized proliferative splenic changes in dogs, veterinarians opt for surgical treatment (total or partial splenectomy) without a prior definitive diagnosis of the lesion. Nevertheless, surgical excision of the spleen eliminates an important source of blood reserve. It may also cause less tolerance to exercise, inadequate response to hypoxia and shock, besides increasing susceptibility to microbial infections, erythrocyte parasitism, sepsis and cardiovascular complications (Nyland et al. 2005). Thus, ideally, this procedure would be performed only when beneficial for the patient (Eberle et al. 2012).

Many retrospective studies show that non-neoplastic spleen lesions in splenectomized dogs are more frequent than neoplastic lesions (Day et al. 1995, Christensen et al. 2009, Campos 2010, Bandinelli et al. 2011, Eberle et al. 2012, Dionísio 2016). There are more international epidemiological studies on splenic lesions (Hosgood 1987, Day et al. 1995, Christensen et al. 2009, Eberle et al. 2012, Dionísio 2016) than Brazilian ones (Campos 2010, Bandinelli et al. 2011, Rodigheri et al. 2015, Martins 2017).

Abdominal ultrasound imaging is a valuable diagnostics modality in the clinical routine of small animal care; it is non-invasive, fast, and low-cost compared to more complex techniques, and allows for evaluation of the internal architecture and identification of focal or diffuse lesions in abdominal organs, as well as detection of free abdominal fluid (Watson \& Bunch 2010). Nevertheless, a definitive diagnosis of proliferative lesions (hyperplastic or neoplastic) requires a cytological or histopathological evaluation (Thrall 2004).

To avoid unnecessary invasive surgical procedures (laparotomy with incisional/excisional biopsy or partial/total splenectomy) or to confirm diagnoses of splenic lesions identified by ultrasound scan, one alternative would be collecting lesion samples for microscopic evaluation by fine-needle aspiration (FNA) or ultrasound-guided Tru-Cut biopsy of the spleen. A study recently evaluated the use of ultrasound-guided FNA to diagnose splenic lesions in 24 dogs. The study obtained $70.83 \%$ diagnostic precision, which indicates that FNA followed by cytological analysis is a satisfactory complementary technique associated with ultrasound imaging (Martins 2017). Some medical studies have shown that ultrasound-guided fragment biopsies are safe and allow for conclusive diagnosis of splenic lesions 
(Lindgren et al. 1985, Lucey et al. 2002, Lieberman et al. 2003, Tam et al. 2008).

It is worth noting that, in order to prevent complications related to the collection of splenic samples by means of these techniques, particularly abdominal bleeding, the coagulogram must be previously evaluated and sample collection from hypervascular or cystic lesions must be avoided (Lucey et al. 2002).

This study aimed to determine the frequency of the different types of lesion occurring in splenectomized dogs' spleens over a period of 12 years (2006-2017) and the representativeness of neoplastic (benign and malignant) and non-neoplastic lesions, to evaluate and compare the safety and efficiency of fine-needle aspiration (FNA) and ultrasound-guided Tru-Cut needle biopsy for cytological and histopathological diagnosis, respectively, of splenic nodular lesions.

\section{MATERIALS AND METHODS}

This study was conducted in accordance with the animal use and experimentation regulation with the approval of the Animal Research Ethics Committee (CEUA) of the "Escola de Medicina Veterinária e Zootecnia" (EMEVZ) of "Universidade Federal da Bahia” (UFBA) under protocol number 38/2017. This study analyzed the biopsy protocols (test orders and histopathological reports) and record books from the Veterinary Pathology Laboratory (LPV) of UFBA's "Hospital de Medicina Veterinária Professor Renato Rodenburg de Medeiros Netto" (HOSPMEV-UFBA) from 2006 to 2017, and from a private veterinary pathology laboratory (LPPV) in the city of Salvador, state of Bahia, referring to the period from 2012 to 2017.

The study included all cases of splenic histopathological evaluation of splenectomized dogs performed by the laboratories, regardless of breed, age or gender. The spleens (fragments or whole) sent to LPV-UFBA belonged mostly to dogs routinely seen at Small Animals Surgical Clinic of HOSPMEV-UFBA and, to a lesser extent, referred by other veterinarians from Salvador and the city's metropolitan region. The samples evaluated by the LPPV came from several veterinary clinics in the city of Salvador and its metropolitan region.

The information on breed, gender, and age described in the biopsy protocols was collected and analyzed, as well as the data on the macroscopic aspect of the splenic lesions and the histopathological diagnosis described in the reports. The histopathological reports evaluated had been written by experienced veterinarian pathologists. The dogs were individually classified according to gender (male and female), breed, and age - puppies (<1 year old), adults (1-8 years old), and elderly ( $>8$ years old). The macroscopic splenic changes were grouped according to their distribution (focal, multifocal, and multifocal to coalescent) and size - nodule $(<3.0 \mathrm{~cm})$ or mass ( $\geq 3.0 \mathrm{~cm}$ ) (Carvalho 2016).

The histopathological diagnoses of the neoplastic lesions were established according to the terminology proposed by Meuten (2002). The diagnoses were grouped into non-neoplastic and neoplastic lesions, and the latter classified as benign or malignant. The non-neoplastic splenic lesions were classified into atrophy, congestion, splenitis, hyperplasia, hematoma, infarction, or rarefaction. All data obtained from the retrospective study were tabulated and systematically aggregated, and the frequency of each lesion was calculated.

In addition to the retrospective study, before the experimental study the veterinarian responsible for the dogs' spleen sample collection received specialized training by an experienced professional. In the pilot experiment, three different semi-automatic disposable Tru-Cut needle gauges (G) - 20,18, and 16G - were assessed before choosing the one used in this study. All needles were Gallini ${ }^{\circledR} 160 \mathrm{~mm}$ long. At this stage, the size and quality of six spleen samples were assessed from the slides made for histopathological analysis by a pathologist. The tissues obtained from the 16G Tru-Cut needle were considered the best-quality tissues that better represented the lesion; therefore, this gauge was chosen for sample collection from the patients in the experimental study.

Seven dogs with splenic focal lesions (nodules or masses, focal or multifocal, larger than $1.5 \mathrm{~cm}$ in diameter) identified by abdominal ultrasound scan were selected regardless of breed, gender or age. All of them had been referred for surgical treatment with splenectomy. These dogs were identified from the routine outpatient care of a private veterinary hospital in Feira de Santana, state of Bahia (BA), and the procedure was performed with the guardians' permission and upon their signature of the free and informed consent form. The ultrasound scan evaluated the following characteristics of the splenic lesion: size, shape, echogenicity, echotexture, vascularization and location in the organ (head, body or tail of the spleen, proximity to parietal or visceral surface, distance to the main splenic vein). The following exclusion criteria were used: 1) splenic lesions that were hypervascularized under evaluation on Doppler mode, due to increased risk of hemorrhage; 2) abdominal effusion, as it hinders ultrasound evaluation of hemorrhage following the procedure; and 3) splenic lesions without solid areas or areas predominantly formed by extensive cavitations with a risk of rupture. The selected dogs underwent biochemical tests - alanine aminotransferase (ALT), alkaline phosphatase (AF), urea and creatinine, hematology (blood count, platelet count and coagulogram), prothrombin time (PT), and activated partial thromboplastin time (APTT). The tests were ran by a private laboratory in Feira de Santana-BA before the procedure for sample collection. The dogs presenting laboratory changes hindering anesthesia or increasing the risk of bleeding/hemorrhage were excluded from the study. The coagulogram tests were performed on the same day or one day before the fine-needle aspiration (FNA) and biopsy.

Twelve-hour food fasting and four-hour water fasting were required prior to anesthesia. Left ventrolateral abdominal trichotomy was performed followed by an ultrasound scan to identify the lesion(s). The exam was conducted using an ultrasound system Mindray Z6, Logic-e GE or Logic F8 GE (ranging from 7 to $12 \mathrm{MHz}$ and 5 to $12 \mathrm{MHz}$ frequency linear transducers). The dogs were anesthetized with IV propofol at 6 to $10 \mathrm{mg} / \mathrm{kg}$ and later intubated and monitored during the entire procedure, until complete recovery. Following anesthesia, the skin was sterilized with chlorhexidine while the animals lied in supine or right lateral position, depending on the location of the lesion to be accessed. The dogs initially underwent FNA followed by the Tru-Cut biopsy with a $16 \mathrm{G}$ needle. In lesions classified as nodules, at least three samples were collected by FNA and one sample by Tru-Cut biopsy. On the other hand, for lesions classified as masses, at least three samples were collected by FNA and two by Tru-Cut biopsy.

The FNA was carried out according to the ultrasound-guided technique described by Menard \& Papageorges (1995) with hypodermic needles of length and gauge chosen as per the depth of the target-lesion. In cases where no contents were perceived by expelling, we attempted aspiration by traction of the $3 \mathrm{ml}$ syringe plunger as a means of pressing material into the needle by the vacuum. After collection, the material obtained was expelled onto a glass slide with the aid of a $10 \mathrm{ml}$ syringe, followed by Squash smear, air drying, and Romanosvsky staining (rapid panoptic). 
For the fragment biopsies, after localization of the lesion with the ultrasound, a small cutaneous incision was made at the entry point of the Tru-Cut needle. The prepared needle was introduced until its tip was positioned at approximately $1 \mathrm{~cm}$ from the region of interest. It was then triggered and the cutting edge advanced to the nodule/mass and quickly returned to the inside of the needle with the collected material. The needle was then removed and the collected sample was placed in a glass vial with $10 \%$ formalin solution for fixation.

Immediately after removing the FNA or biopsy needle from the animal, external pressure was manually applied on the skin with the aid of a chlorhexidine-soaked gauze for approximately 2 minutes with the intention of helping hemostasis. In cases where more than one splenic lesion was found, it was possible to collect samples of more than one nodule, as they could constitute different lesions.

Following the FNA collection and Tru-Cut biopsy, the abdominal ultrasound evaluation was performed in order to subjectively investigate the possibility of hemorrhage by means of identifying free abdominal fluid adjacent to the lesion. After evaluation, each patient was classified into absent, mild, moderate or severe, according to the amount of fluid present. The patients were followed-up for 30 minutes after the procedure; if no fluid was found around the lesion, they were discharged. If fluid was found, the animals were evaluated every 30 minutes for comparison of the quantity of fluid at different times.

All dogs in the experimental group were splenectomized, normally up to 48 hours after collection of ultrasound-guided samples, having the spleen or its nodule fragments referred for gold standard diagnostics histopathological evaluation.

The spleen fragments collected by biopsy and the spleen or fragments referred after splenectomy fixed in $10 \%$ formalin were referred to LPV-UFBA for histopathological analysis, where they were cleaved, dehydrated in absolute ethyl alcohol, clarified in xylol, embedded in paraffin and cut in microtomes at a thickness of $5 \mu \mathrm{m}$. The histological sections obtained were stained with hematoxylin-eosin (HE) and the slides were examined under an optical microscope by two experienced pathologists ( 1 and 2). The diagnosis followed the same classification proposed in the retrospective study.

The cytological slides were blindly evaluated by three different clinical pathologists (Pathologists A, B, and C). The ultrasound evaluations and all collections of splenic material samples of the animals in the experiment, both for cytology and histopathology, were performed by the same examiner.

\section{RESULTS AND DISCUSSION}

\section{Lesions in 224 spleens of splenectomized dogs}

During the retrospective study period (2006-2017), histopathological exams were performed in 7,733 samples from several domestic animal species. Among them, 3,994 samples came from the UFBA LPV diagnostics service (from May 2006 to December 2017) and 3,739 from the LPPV (from April 2012 to December 2017). Of the total, 74.47\% $(5,759 / 7,733)$ corresponded to samples from dogs, from which $45.98 \%(2,648 / 5,759)$ and $54.02 \%(3,111 / 5,759)$ belonged to the LPV-UFBA and LPPV caseloads, respectively. Of the 5,759 dog biopsy protocols reviewed, 3.89\% (224) cases of lesions in splenectomized spleens were found, from which $28.12 \%(63 / 224)$ came from LPV-UFBA and $71.88 \%$ (161/224), from LPPV.

Of the 224 samples of splenic lesions evaluated, 156 (69.65\%) came from total splenectomy and 68 (30.35\%), from partial.
All 224 cases presented conclusive histopathological diagnoses. Table 1 shows the categories of splenic lesions identified with their respective frequencies. Of these 224 cases, $49.55 \%$ (111) were diagnosed as neoplastic lesions and 50.45\% (113) as non-neoplastic. Of the animals with splenic neoplasia diagnosis, 79.27\% (88/111) presented malignant neoplasias and $20.73 \%$ (23/111), benign (hemangioma).

Among the non-neoplastic lesions, the hyperplastic changes were the most frequent (59.29\%, 67/113), followed by splenic hematoma (18.58\%, 21/113), splenic infarction (10.62\%, 12/113), splenitis (5.31\%, 6/113), splenic atrophy (4.42\%, 5/113), and splenic congestion (1.77\%, 2/113). With regard to neoplastic lesions, the most frequent was hemangiosarcoma $(52.25 \%, 58 / 111)$, followed by hemangioma (20.72\%, 23/111), lymphoma (17.11\%, 19/111), poorly differentiated sarcoma and fibrosarcoma (2.71\%, 3/111 each), and mammary carcinoma, spindle cell sarcoma, histiocytic sarcoma, leiomyosarcoma, and round cell tumors (0.90\%, 1/111 each).

With regard to the total of diagnoses found in this study, 20 different diagnoses of splenic lesions were found, divided into two categories (neoplastic and non-neoplastic lesions). Among them, the hyperplastic were the most frequent, corresponding to $29.91 \%(67 / 224)$ of the total of diagnoses. The second most common change among the total of diagnoses was hemangiosarcoma (HSA), which was observed in $25.89 \%$ $(58 / 224)$ of cases. Upon separate analysis of the five subtypes among the 67 hyperplastic lesions found, in the group of non-neoplastic changes (113 cases), nodular lymphoid

Table 1. Frequency of neoplastic and non-neoplastic lesions in 224 spleens of splenectomized dogs (2006-2017)

\begin{tabular}{|c|c|c|c|}
\hline Histopathological diagnosis & $\begin{array}{c}\text { Number of } \\
\text { diagnoses }\end{array}$ & $\begin{array}{c}\% \text { of } \\
\text { category }\end{array}$ & $\begin{array}{l}\% \text { of } \\
\text { total }\end{array}$ \\
\hline \multicolumn{4}{|l|}{ Neoplastic $(n=111)$} \\
\hline Hemangiosarcoma & 58 & $52,25 \%$ & $25,89 \%$ \\
\hline Hemangioma & 23 & $20,73 \%$ & $10,26 \%$ \\
\hline Lymphoma & 19 & $17,12 \%$ & $8,48 \%$ \\
\hline Splenic fibrosarcoma & 3 & $2,70 \%$ & $1,34 \%$ \\
\hline Poorly differentiated sarcoma & 3 & $2,70 \%$ & $1,34 \%$ \\
\hline Leiomyosarcoma & 1 & $0,90 \%$ & $0,45 \%$ \\
\hline Metastasis Mammary carcinoma & 1 & $0,90 \%$ & $0,45 \%$ \\
\hline Round cell sarcoma & 1 & $0,90 \%$ & $0,45 \%$ \\
\hline Spindle cell sarcoma & 1 & $0,90 \%$ & $0,45 \%$ \\
\hline Histiocytic sarcoma & 1 & $0,90 \%$ & $0,45 \%$ \\
\hline \multicolumn{4}{|l|}{ Non-neoplastic $(\mathrm{n}=113)$} \\
\hline \multicolumn{4}{|l|}{ Splenic hyperplasia } \\
\hline Nodular lymphoid & 56 & $49,55 \%$ & $25,00 \%$ \\
\hline Nodular age-related (senile) & 6 & $5,31 \%$ & $2,68 \%$ \\
\hline White pulp & 3 & $2,65 \%$ & $1,34 \%$ \\
\hline Follicular & 1 & $0,89 \%$ & $0,45 \%$ \\
\hline Intense reactive & 1 & $0,89 \%$ & $0,45 \%$ \\
\hline Hematoma & 21 & $18,58 \%$ & $9,37 \%$ \\
\hline Splenic infarction & 12 & $10,62 \%$ & $5,35 \%$ \\
\hline Splenitis & 6 & $5,31 \%$ & $2,68 \%$ \\
\hline Atrophy & 5 & $4,42 \%$ & $2,22 \%$ \\
\hline Splenic congestion & 2 & $1,77 \%$ & $0,89 \%$ \\
\hline Total of diagnoses & 224 & & $100 \%$ \\
\hline
\end{tabular}


hyperplasia was the most frequent (83.58\%, 56/67), followed by age-related (senile) nodular hyperplasia $(8.95 \%, 6 / 67)$, white pulp hyperplasia $(4.47 \%, 3 / 67)$, follicular hyperplasia, and intense reactive hyperplasia (1.5\%, 1/67 each).

Considering the total of cases, the possibility of benign splenic lesions occurring $(60.71 \%, 136 / 224$ corresponding to 23 benign neoplasias and 113 non-neoplastic lesions) was higher than the malignant $(39.29 \%, 88 / 224)$, with a ratio of 1.52 between them. This result is corroborated by international studies, in which non-neoplastic lesions in dog spleens were more frequent than neoplastic lesions (Day et al. 1995, Christensen et al. 2009, Dionísio 2016), as was also verified in a study conducted at "Universidade de São Paulo" (Campos 2010). In spite of the small differences in percentage of the neoplastic and non-neoplastic diseases in the abovementioned studies - 4\% in 109 cases (Campos 2010), 12\% in 87 cases (Day et al. 1995), 14\% in 120 cases (Christensen et al. 2009), and 20\% in 91 cases (Dionísio 2016) these differences were considerably higher than that found in this study $(0.9 \%)$.

Conversely, in other works, neoplastic lesions were more frequent than non-neoplastic ones, with a difference between them of $4 \%$ in 31 cases (Hosgood 1987), 18.6\% in 32 cases (Rodigheri et al. 2015), and $38.6 \%$ in 179 cases (Bandinelli et al. 2011). In this study, by analyzing neoplasias individually (111), the biologically malignant ones $(79.27 \%, 88 / 111)$ were found to be considerably more frequent than the benign $(20.73 \%, 23 / 111)$. The ratio between them is 3.83 , i.e. the possibility of a malignant neoplasia occurring was $74 \%$ higher than that of a benign neoplasia. It is worth noting that the number of cases evaluated in our study (224) was much higher, which may justify the difference found. It is reasonable to consider that the greater the caseload evaluated, the higher the representability of the samples. Therefore, there may in fact be a similar prevalence between neoplastic and non-neoplastic lesions in dogs.

Eberle et al. (2012) verified, in a retrospective study conducted in Hannover with 249 dogs, 132 (53\%) cases of neoplastic splenic lesions. Among them, 97 (73.5) consisted in HSA, which corroborates our findings, since HSA was the most frequent neoplasia representing $52.25 \%$ (58/111) of neoplasias. Differing malignant and benign splenic lesions before splenectomy is important to allow for more appropriate therapeutic conduct and, consequently, to keep the organ in cases of uncomplicated benign lesions, which would avoid greater-risk situations caused by the absence of the spleen due to lower tolerance to exercise, inadequate response to hypoxia and shock, besides increasing susceptibility to microbial infections, erythrocyte parasitism, sepsis and cardiovascular complications. Upon prior diagnosis, it is suggested that splenectomy be conducted only in cases where surgical excision can be beneficial for the patient (Eberle et al.2012).

Regarding gender, of the 224 biopsy protocols analyzed, only one $(0.45 \%, 1 / 224)$ did not indicate the gender. Of the $223(99.55 \%)$ dogs whose gender was informed, the female $(52.47 \%, 117 / 223)$ were a little more affected than the male dogs $(47.53 \%, 106 / 223)$. In females, there was a higher occurrence of both neoplastic $(52.25 \%, 58 / 111)$ and non-neoplastic lesions $(52.68 \%, 59 / 112)$ in relation to the males. However, this difference was not significant. Other works also report insignificant differences between the genders of the affected animals (Hammond \& Pesillo-Crosby 2008, Christensen et al.
2009, Campos 2010, Bandinelli et al. 2011, Rodigheri et al. 2015, Dionísio 2016).

The age was informed in $94.64 \%$ (212/224) of the cases. Elderly animals were most frequently affected and represented more than three quarters of cases $(77.83 \%, 165 / 212)$ followed by adults, with representativity below one quarter of cases $(22.17 \%, 47 / 212)$. No puppies were affected. The 12 dogs whose ages were not specified corresponded to $5.36 \%(12 / 224)$ of the total of cases. Among the neoplastic lesions, the mean age of the affected dogs was 10.3 years and, for non-neoplastic lesions, 10.1 years. Hyperplastic splenic lesions were the most frequent among the non-neoplastic lesions (59.29\%), with a mean age of 11.2 years; the least frequent lesion found in this study was HSA $(52.25 \%)$, occurring in dogs with an average age of 10 years. This confirms that the probability of splenic lesions in aged dogs is considerably higher than in adults, as the ratio between them is 3.51. Similar findings have been described in the literature (Hosgood 1987, Prymak et al. 1988, Johnson et al. 1989, Day et al. 1995, Hammond \& Pesillo-Crosby 2008, Bandinelli et al. 2011, Rodigheri et al. 2015), which reiterates the importance of routinely investigating lesions of this nature in these patients, especially due to their predisposition to develop HSA and splenic hematomas (Aronsohn et al. 2009).

As to the breeds of the dogs affected by splenic lesions, a great variety was found in this study (31 different breeds). Of the 212 dogs with identified breed pattern, 47 (22.17\%) were mixed-breed (MBD) and 165 (77.83\%) were purebred. Among them, the most frequent were Poodle $(13.68 \%$, 29/212), Shih Tzu and Yorkshire (7.55\%, 16/212 each), Cocker Spaniel (6.13\%,13/212), and Pit Bull (5.19\%, 11/212). The breed was not informed on the biopsy protocol in 12 cases $(5.36 \%, 12 / 224)$.

In the present study, mixed-breed dogs (MBD) were the most frequently affected, which may reflect the fact that mixed-breed animals represent the majority of the canine population in Brazil (Fonseca 1999, Hataka 2004) and the patient population seen at HOSPMEV-UFBA itself, which comes mostly from low-income neighborhoods - as per the IBGE (Brazilian Institute of Geography and Statistics) classification - according to a recent georeferencing study conducted by Machado (2017). Bandinelli et al. (2011) suggested higher rates of development of HSA in MBD, which represented $27.9 \%$ $(50 / 179)$ in their study, followed by the breeds Rottweiler 8.9\% (16/179) and Cocker Spaniel 8.4\% (15/179).

With regard to the size of splenic lesions, of the $113(100 \%)$ non-neoplastic changes, $112(99.1 \%)$ had their size specified in the biopsy protocols and, of these, $67 \%(75 / 112)$ were classified as nodules (smaller than $3.0 \mathrm{~cm}$ ) and 33\% (37/112), as a mass (larger than $3.0 \mathrm{~cm}$ ) (Table 2). Upon evaluation of the size of the $111(100 \%)$ neoplastic lesions, $75 \%(83 / 111)$ were found to be masses and 25\% (28/111), nodules. Among

Table 2. Size of lesions found in the 224 spleens of splenectomized dogs

\begin{tabular}{lcccc}
\hline Nature of lesion & Nodule $(<3.0 \mathrm{~cm})$ & Mass $(>3.0 \mathrm{~cm})$ & NI $^{\mathrm{a}}$ & Total \\
\hline $\begin{array}{c}\text { Non-neoplastic } \\
\text { Size }\end{array}$ & 75 & 37 & 1 & 113 \\
$\begin{array}{c}\text { Neoplastic } \\
\text { Size }\end{array}$ & 28 & & & \\
\hline
\end{tabular}

${ }^{\mathrm{a}} \mathrm{NI}=$ not informed 
Table 3. Distribution of lesions found in the 224 spleens of splenectomized dogs

\begin{tabular}{lccccc}
\hline Nature of lesion & Focal & Multifocal & $\begin{array}{c}\text { Multifocal to } \\
\text { coalescent }\end{array}$ & NI $^{\mathrm{a}}$ & Total \\
\hline $\begin{array}{c}\text { Non-neoplastic } \\
\quad \begin{array}{c}\text { Distribution } \\
\text { Neoplastic }\end{array}\end{array}$ & 73 & 39 & 0 & 1 & 113 \\
$\quad \begin{array}{l}\text { Distribution } \\
{ }^{\mathrm{a}} \mathrm{NI}=\text { not informed. }\end{array}$ & 55 & 49 & 7 & 0 & 111 \\
\hline
\end{tabular}

the 56 cases of nodular lymphoid hyperplasia diagnosed in this study, $83.92 \%(47 / 56)$ were nodules and $16.08 \%(9 / 56)$, masses; among the 58 HSA, $67.24 \%$ (39/58) were nodules and $32.76 \%(19 / 58)$, masses.

As to the distribution of non-neoplastic lesions described in $99.11 \%(112 / 113)$ of the cases, the focal lesions were more frequent $(65.17 \%, 73 / 112)$ than the multifocal $(34.83 \%, 39 / 112)$. With regard to the neoplastic lesions, 49.55\% (55/111) were focal, $44.15 \%$ (49/111) multifocal and, less frequently, $6.30 \%(7 / 111)$ multifocal to coalescent (Table 3). In the cases of nodular lymphoid hyperplasia and HSA, the focal distribution was more frequent and corresponded to $71.42 \%$ (40/56) and 58.62\% (34/58) of cases, respectively. As to the size and distribution of non-neoplastic splenic lesions, $67 \%$ were smaller than $3.0 \mathrm{~cm}$, where $65.17 \%$ were focal. This finding indicates that small focal lesions are more likely to constitute non-neoplastic changes. In the experimental study, it was verified that, despite the low frequency $(n=7), 100 \%$ of the multifocal to coalescent lesions were neoplastic. In the reviewed literature, no works evaluating these parameters in canine splenic nodules were found.

\section{Evaluation of alternative techniques for prior microscopic diagnosis}

In the experimental study, it was verified that both the FNA and the Tru-Cut biopsy with a $16 \mathrm{G}$ needle presented low risk of complications; therefore, they may be considered safe. No complications were observed in the dogs submitted to FNA and only $14.28 \%$ (1/7) of the Tru-Cut biopsies resulted in a mild fluid collection adjacent to the lesion, identified by means of an ultrasound scan performed after the procedure. In this isolated case, the lesion appeared to be multifocal heterogeneous with cavitations, which may explain the increased risk of bleeding or even rupture of one of the cavity areas. However, the patient did not present clinical changes and, during the ultrasound monitoring period, the amount of fluid gradually decreased and the animal was subsequently discharged. No correlation was found between the coagulogram lab findings and the occurrence of hemorrhagic complications after collection of samples by ultrasound-guided FNA and fragment biopsy using 16G Tru-Cut needles. It is worth highlighting that, in all collections carried out by both techniques, none of the dogs presented changes in the clinical signs indicating significant blood loss, and no surgical intervention was required to control bleeding.

It is noteworthy that the Tru-Cut biopsy has been more widely performed in the medicine and has proven to be an accurate and safe procedure with high diagnostic value for splenic lesions, with over $91 \%$ of reportedly conclusive diagnoses and reduced complication rate (Lucey et al. 2002,
Lieberman et al. 2003). Cunha (2009) compared the FNA and 14G Tru-Cut biopsy techniques for canine testicles and concluded that both methods presented low risk for the patient, are easily employed, and allow for collection of enough material for diagnosis. However, in humans, similar studies presented more expressive complications, especially in the Tru-Cut biopsies compared to FNA, which required, in some cases, blood transfusions and even splenectomy due to hemorrhage, in up to $10.3 \%$ of cases (Lindgren et al. 1985, Lucey et al. 2002).

The splenic ultrasound evaluation identified nodular lesions bigger than $1.5 \mathrm{~cm}$ or splenic masses in all seven dogs in this study. However, the ultrasound characteristics of the splenic lesions varied and, due to the small size of the sample and the variation of final diagnoses, it was not possible to establish a correlation of the image patterns of the lesions with the histopathological diagnoses.

In the five cases of malignant lesions confirmed by the histopathological exam following splenectomy, a tendency for multiple lesions identified as masses was observed. The ultrasound scan was useful in guiding the needle to the lesion of interest, as they were easily recognizable during the procedure. Most of the time, it was necessary to apply superficial pressure for the Tru-Cut needle to pass through the subcutaneous tissue, musculature and peritoneum, even with prior skin incision. This is attributed to the gauge of the needle and the cutting capacity of the needle brand chosen.

The list of microscopic diagnoses of the splenic nodular lesions obtained by the different techniques pre-splenectomy (FNA and Tru-Cut) and post-splenectomy (histopathology) are found in Table 4 for comparison. The cytological samples were normally hypercellular; however, some slides were fixed with formalin steam, which hindered proper staining and, consequently, microscopic visualization. At times, accentuated blood contamination was also observed, which led to inconclusive diagnosis of the samples.

Of the 21 possible cytological diagnoses for the seven animals evaluated by the three clinical pathologists, $28.57 \%$ $(6 / 21)$ were inconclusive and $71.43 \%(15 / 21)$, conclusive. Of the conclusive diagnoses, $73.33 \%(11 / 15)$ were classified as neoplastic and $26.67 \%$ (4/15), non-neoplastic lesions. Of the conclusive diagnosis, $60 \%$ (9/15) were compatible with the histopathological splenectomy diagnosis. These cytological results obtained by the FNA showed that this technique, simple and low-cost, may help investigate splenic nodular lesions in veterinary clinical routine, since the rate of conclusive diagnoses was high (71.43\%), with $60 \%$ accuracy in relation to the post-splenectomy histopathological results (gold standard).

A similar result was obtained in a recent survey, which performed ultrasound-guided FNA in 24 dogs with splenic lesions and produced diagnoses with $62.5 \%$ sensitivity, $87.5 \%$ specificity, and $70.83 \%$ accuracy (Martins 2017). Therefore, FNA may be considered a complementary technique providing satisfactory results when associated with ultrasound scan and histopathology.

Medical studies of this nature have also presented good results. About three samples obtained by FNA per splenic lesion with needles gauge 20,22 , and $23 \mathrm{G}$ achieved a definitive diagnosis in $95 \%$ of the cases (Lucey et al. 2002). In a retrospective study conducted in the United States, of 156 cases of material 
Table 4. Comparison of the microscopic diagnoses of nodular splenic lesions obtained by alternative techniques pre- and post-splenectomy

\begin{tabular}{|c|c|c|c|c|c|}
\hline \multirow{3}{*}{ Dog } & \multicolumn{4}{|c|}{ Diagnosis prior to splenectomy } & \multirow{3}{*}{$\begin{array}{c}\text { Histopathological } \\
\text { diagnosis } \\
\text { post-splenectomy } \\
\text { Pathologist } 1 \text { and } 2\end{array}$} \\
\hline & \multicolumn{3}{|c|}{ FNA cytology } & Biopsy by Tru-Cut & \\
\hline & Pathologist A & Pathologist B & Pathologist C & Pathologist 1 and 2 & \\
\hline 1 & Inconclusive & Hemangiosarcoma & Inconclusive & Hemangiosarcoma & Hemangiosarcoma \\
\hline 2 & Inconclusive & $\begin{array}{l}\text { Extramedullary } \\
\text { hematopoiesis }\end{array}$ & $\begin{array}{l}\text { Extramedullary } \\
\text { hematopoiesis }\end{array}$ & Inconclusive & Lymphoma \\
\hline 3 & Mastocytoma metastasis & Mastocytoma metastasis & Mastocytoma metastasis & Inconclusive & Hemangiosarcoma \\
\hline 4 & Lymphoma & Lymphoma & Lymphoma & Lymphoma & Lymphoma \\
\hline 5 & Sarcoma & Hemangiosarcoma & Sarcoma & Hemangiosarcoma & Hemangiosarcoma \\
\hline 6 & Inconclusive & Inconclusive & Inconclusive & Hematoma & Hematoma \\
\hline 7 & Reactive spleen & Lymphoma & Reactive spleen & Nodular hyperplasia & Nodular hyperplasia \\
\hline
\end{tabular}

collected with imaging guidance, a conclusive diagnosis with cytological exam was obtained in 131 cases (83.9\%), most of them with $22 \mathrm{G}$ needles and collection of 2.8 samples per lesion, on average, with a variation of 1 to 6 samples. Thus, in only 25 cases (16.1\%), the samples collected by FNA were not enough to close the diagnosis and required fragment collection by Tru-Cut needles (Tam et al. 2008).

Some factors may explain the fact that the results obtained by the FNA, in our study, were not more satisfactory, such as faults in smearing, blood contamination of samples and even the number of samples collected per animal. According to Christopher (2003), poor exfoliation of mesenchymal tumor cells during cytological collection hinders conclusive diagnosis. Controlling these factors can significantly reduce these faults and, consequently, increase the chances of success in cytological diagnosis (FNA) of splenic nodular lesions prior to splenectomy. In this study, most of the lesions not diagnosed by the cytological exam were hemangiosarcoma, a highly vascularized neoplasia that is difficult to diagnose by cytology due to low exfoliation of neoplastic cells and high blood contamination.

As to Tru-Cut biopsy, of the seven samples evaluated, $71.43 \%$ (5/7) presented conclusive diagnoses, while $28.57 \%$ (2/7) were inconclusive (Table 4). Among the conclusive diagnoses, $60 \%(3 / 5)$ of the lesions were neoplastic and $40 \%$ (2/5), non-neoplastic. All of the samples collected by Tru-Cut that resented conclusive histopathological diagnoses were compatible with the histopathological diagnoses obtained after splenectomy (gold standard) and, therefore, may be considered a good alternative technique for prior microscopic diagnosis of nodular splenic lesions. Studies conducted with dogs evaluating Tru-Cut biopsy techniques in splenic lesions were not found.

Laufer-Amorim et al. (2002) evaluated, the kidney biopsy technique with $14 \mathrm{G}$ Tru-Cut needles in dogs, having concluded that it was possible to determine the morphological diagnosis of diffuse nephropathies. Melchert et al. (2010) stated that the use of 16G Tru-Cut needles in dogs and also for kidney biopsies allowed for diagnosis without major complications or death, which points to a high diagnostic value. In medicine, it was also possible to diagnose primary or recurrent lymphoma by ultrasound-guided splenic biopsy using a 20 or $22 \mathrm{G}$ needle in 18 patients (90\%) (Lieberman et al. 2003).

In this study, the results of the histopathological exams of the fragments collected by the 16G Tru-Cut needle were considered satisfactory, although in two cases the diagnosis were inconclusive, which was attributed to the limited number of samples (one per lesion), as well as to the choice of place for collection - which is expected, in some cases, in this type of exam. It may be said that a higher amount of samples is required to evaluate the real frequency of errors and successes of the different diagnostic modalities and to propose an agreement rate between them.

Post-splenectomy histopathological evaluation of splenic lesion samples allowed for the comparison of Tru-Cut cytological and histopathological results of the seven dogs. The samples generated by the splenectomies presented conclusive diagnoses in $100 \%(7 / 7)$ of the cases (Table 4), $71.43 \%(5 / 7)$ of which were neoplastic and $28.57 \%(2 / 7)$, non-neoplastic. It is worth noting that the splenic lesion samples obtained post-splenectomy allowed for evaluation of large extents of nodules, which allowed for the establishment of the definitive diagnosis and the conclusion and diagnostic agreement between both pathologists.

Preliminarily, although the three clinical pathologists $(\mathrm{A}, \mathrm{B}$, and $\mathrm{C})$ presented the same diagnostic agreement rate with the post-splenectomy histopathological results $(3 / 7,42.8 \%)$, the different results obtained among evaluators shows that the pathologist's experience in cytological evaluation may influence the results of reading the slides. Therefore, it is clear that the alternative techniques for pre-splenectomy microscopic diagnosis of splenic nodular lesions evaluated here present some technical limitations and require particular care. This fact was detected by the occurrence of technical difficulties during collection (individual ability and choice of place), as well as by the reduced number of samples collected from each lesion.

These conclusions reiterate the importance and need for a training both for material collection (FNA and Tru-Cut) and reading and interpretation of cytological slides. Professional qualification in sample collection by means of training in animal corpses with the aim to perfect individual abilities may be an alternative.

\section{CONCLUSIONS}

Splenic lesions in dogs represented about $4 \%$ of the caseloads of the Veterinary Pathology Laboratories. Among them, the most frequent are hemangiosarcoma, splenic hyperplasia, hemangioma, hematoma, lymphoma, and 
infarction. The frequency of neoplastic and non-neoplastic splenic lesions was similar.

The possibility of benign splenic lesions in dogs is 1.52 times higher than malignant; however, splenic neoplasias are four times more likely to be malignant than benign. Splenectomy could have been avoided in $61 \%$ of the dogs if conclusive microscopic exams had been performed before surgery to diagnose the nature of the lesion and prevent unnecessary excision of the spleen in animals affected by benign lesions.

Both techniques evaluated, FNA and Tru-Cut needle biopsy, present low risk of complication after sample collection. They were considered safe and a good alternative to microscopic diagnosis of nodular splenic lesions. These techniques are recommended mostly for dogs with focal splenic lesions under three centimeters.

Conflict of interest statement.- The authors have no competing interests.

\section{REFERENCES}

Aronsohn M.G., Dubiel B., Roberts B. \& Powers B.E. 2009. Prognosis for acute nontraumatic hemoperitoneum in the dog: a retrospective analysis of 60 cases (2003-2006). J. Am. Anim. Hosp. Assoc. 45(2):72-77. <http://dx.doi. org/10.5326/0450072><PMid:19258418>

Bandinelli M.B., Pavarini S.P., Oliveira E.C., Gomes D.C., Cruz C.E.F. \& Driemeier D. 2011. Estudo retrospectivo de lesões em baços de cães esplenectomizados: 179 casos. Pesq. Vet. Bras. 31(8):697-701. <http://dx.doi.org/10.1590/ S0100-736X2011000800011>

Campos A.G. 2010. Esplenomegalias em cães: estudo retrospectivo e análise imunohistoquímica do Fator de Crescimento Endotelial Vascular (VEGF). Master's Thesis, Faculdade de Medicina Veterinária e Zootecnia, Universidade de São Paulo, São Paulo, SP. 74p.

Carvalho F.C. 2016. Ultrassonografia intervencionista, p.229-308. In: Carvalho F.C. (Ed.), Ultrassonografia em Pequenos Animais. $2^{\underline{a}}$ ed. Roca, São Paulo.

Christensen N.I., Canfield P.J., Martin P.A., Krockenberger M.B., Spielman D.S. \& Bosward K.L. 2009. Cytopathological and histopathological diagnosis of canine splenic disorders. Aust. Vet. J. 87(5):175-181. <http://dx.doi. org/10.1111/j.1751-0813.2009.00421.x><PMid:19382924>

Christopher M.M. 2003. Cytology of the spleen. Vet. Clin. N. Am., Small Anim. Pract.33(1):135-152. <http://dx.doi.org/10.1016/S0195-5616(02)000827> <PMid:12512380>

Cunha G.N. 2009. Estudo da viabilidade do uso da punção biópsia aspirativa por agulhas fina comparada ao da "tru-cut", em testículos de cães. Doctoral Dissertation, Faculdade de Ciências Agrárias, Universidade Estadual Paulista, Jaboticabal, SP. 45p.

Day M.J., Lucke V.M. \& Pearson H. 1995. A review of pathological diagnoses made from 87 canine splenic biopsies. J. Small Anim. Pract. 36(10):426-433. <http://dx.doi.org/10.1111/j.1748-5827.1995.tb02769.x><PMid:8583757>

Dionísio M.I.M. 2016. Prevalência da doença esplénica em cães e sobrevivência após esplenectomia - estudo retrospetivo. 2016. Doctoral Dissertation, Universidade de Lisboa, Portugal. 94p.

Eberle N., von Babo V., Nolte I., Baumgärtner W. \& Betz D. 2012. Splenic masses in dogs. Part 1: epidemiologic, clinical characteristics as well as histopathologic diagnosis in 249 cases (2000-2011). Tierärztliche Praxis Kleintiere 40(4):250-260. <PMid:22911256>

Fonseca C.S. 1999. Avaliação dos níveis séricos do estradiol e progesterona em cadelas portadoras de neoplasias mamárias. Master's Thesis, Faculdade de Ciências Agrárias, Universidade Estadual Paulista, Jaboticabal, SP. 87p.

Hammond T.N. \& Pesillo-Crosby S.A. 2008. Prevalence of hemangiosarcoma in anemic dogs with a splenic mass and hemoperitoneum requiring a transfusion: 71 cases (2003-2005). J. Am. Vet. Med. Assoc. 232(4):553558. <http://dx.doi.org/10.2460/javma.232.4.553><PMid:18279091>

Hataka A. 2004. Citologia aspirativa com agulha fina e histopatologia:valor e significado para diagnóstico e prognóstico do câncer de mama em cadelas.
Doctoral Dissertation, Faculdade de Medicina Veterinária e Zootecnia, Universidade Estadual Paulista, Botucatu, SP. 98p.

Hosgood G. 1987. Splenectomy in the dog: a retrospective study of 31 cases. J. Am. Anim. Hosp. Assoc. 32(3):275-283.

Johnson K.A., Powers B.E., Withrow S.J., Sheetz M.J., Curtis C.R. \& Wrigley R.H. 1989. Splenomegaly in dogs - predictors of neoplasia and survival after splenectomy. J. Vet. Intern. Med. 3(3):160-166. <http://dx.doi. org/10.1111/j.1939-1676.1989.tb03092.x><PMid:2778749>

Laufer-Amorim R., Bandarra E.P., Monteiro L.A. \& Moura V.M.B.D. 2002. Avaliação quantitativa e qualitativa da técnica de biopsia renal "de janela" em cães. Ciênc. Anim. Bras. 3(2):41-45.

Lieberman S., Libson E., Maly B., Lebensart P., Ben-Yehuda D. \& Bloom A.I. 2003. Imaging-guided percutaneous splenic biopsy using a 20- or 22-Gauge cutting-edge core biopsy needle for the diagnosis of malignant lymphoma. Am. J. Roentgenol. 181(4):1025-1027. <http://dx.doi.org/10.2214/ ajr.181.4.1811025> <PMid:14500223>

Lindgren P.G., Hagberg H., Eriksson B., Glimelius B., Magnusson A. \& Sundstrom C. 1985. Excision biopsy of the spleen by ultrasound guidance. Brit. J. Radiol. 58(693):853-857. <http://dx.doi.org/10.1259/0007-1285-58693-853><PMid:3916062>

Lucey B.C., Boland G.W., Maher M.M., Hahn P.F., Gervais D.A. \& Mueller P.R. 2002. Percutaneous nonvascular splenic intervention: a 10-year review. Am. J. Roentgenol. 179(6):1591-1596. <http://dx.doi.org/10.2214/ ajr.179.6.1791591><PMid:12438060>

Machado G.A.C. 2017. Dermatopatias diagnosticadas em cães no hospital de medicina veterinária da Universidade Federal da Bahia por avaliações histopatológicas (2007-2016) e clínico-laboratoriais (2015-2017), UFBA. Master's Thesis, Universidade Federal da Bahia, Salvador, BA. 117p.

Martins K.P.F. 2017. Caracterização ultrassonográfica e citológica de lesões esplênicas de cães comparadas ao diagnóstico histopatológico. Master's Thesis, Universidade de Cuiabá, Cuiabá, MT. 68p.

Melchert A., Moutinho F.Q., Mamprim M.J. \& Santos F.A.M. 2010. Biopsia renal percutânea monitorizada por ultrassonografia em cães. Ciênc. Anim. Bras. 11(2):447-453. <http://dx.doi.org/10.5216/cab.v11i2.4915>

Menard M. \& Papageorges M. 1995. Ultrasound corner technique for ultrasound-guided fine needle biopsies. Vet. Radiol. Ultrasound 36(2):137138. <http://dx.doi.org/10.1111/j.1740-8261.1995.tb00233.x>

Meuten D.J. 2002. Tumors in Domestic Animals. 4th ed. Iowa State Press, Ames, Iowa. 800p. <http://dx.doi.org/10.1002/9780470376928>>.

Nyland T.G., Mattoon J.S., Herrgesell E.J. \& Wisner E.R. 2005. Baço, p.131-145. In: Nyland T.G. \& Mattoon J.S. (Eds), Ultra-som Diagnóstico em Pequenos Animais. $2^{\text {a }}$ ed. Roca, São Paulo.

Prymak C., Mckee L.J., Goldschmidt M.H. \& Glickman L.T. 1988. Epidemiologic, clinical, pathologic, and prognostic characteristics of splenic hemangiosarcoma and splenic hematoma in dogs: 217 cases. J. Am. Vet. Med. Assoc. 193(6):706712. <PMid:3192450>

Rodigheri S.M., Campos G.F. \& Romani M.S. 2015. Avaliação clínica, hematológica e histopatológica de tumores esplênicos em cães. $42^{\circ}$ Congresso Brasileiro de Medicina Veterinária e 1ํㅡㄹ Congresso Sul-Brasileiro da ANCLIVEPA, Curitiba, PR, p.2305-2309. (Resumo)

Tam A., Krishnamurthy S., Pillsbury E.P., Ensor J.E., Gupta S., Murthy R., Ahrar K., Wallace M.J., Hicks M.E. \& Madoff D.C. 2008. Percutaneous imageguided splenic biopsy in the oncology patient: an audit of 156 consecutive cases. J. Vasc. Interv. Radiol. 19(1):80-87. <http://dx.doi.org/10.1016/j. jvir.2007.08.025><PMid:18192471>

Thrall D.E. 2004. Oncologic imaging: focus on form or function? Proceedings World Small Animal Veterinary Association World Congress. (Resumo)

Tilson D.M. 2003. Spleen, p.1046-1062. In: Slatter D.H. (Ed.), Textbook of Small Animal Surgery. W.B. Saunders, Philadelphia.

Watson P.J. \& Bunch S.E. 2010. Biopsia hepática, p.512. In: Nelson R.W. \& Couto C.G. (Eds), Medicina Interna de Pequenos Animais. $4^{\mathrm{a}}$ ed. Elsevier, Rio de Janeiro. 